\title{
EENE REIS NAAR ST. MAARTEN IN OORLOGSTIJD
}

\author{
DOOR
}

\section{IR. F. S. LANGEMEYER}

In het einde van 1917 had Duitschland de verscherpte duikboot-oorlog aangekondigd. Tegenmaatregelen der gealliëerden bleven niet uit. De toestand der neutrale zeevaarders werd er niet gemakkelijker op. Vooral niet sinds de Vereenigde Staten, de machtigste der neutralen, partij had gekozen. Met de overblijvende neutralen behoefde weinig rekening te worden gehouden. Macht beteekende in die dagen slechts overmacht, en op protesten werd niet veel acht geslagen. Aan geen van beide zijden.

Dit had tot gevolg, dat de passagiersvaarten ingekrompen waren in aantal, en dat de varende schepen overvuld werden. De op Nederlandsch-Indië varende maatschappijën voeren reeds sedert lang niet meer hun gewone route, daar het Suezkanaal oorlogsgebied en ook de Middellandsche Zee al te onveilig was. De oude vaarweg over de Kaap de Goede Hoop was een tijd lang wederom in gebruik geraakt, doch ook deze scheen begin 1918 niet meer geraden. De reis naar de Oost ging in dien tijd via NewYork en San Francisco, waarbij dan de Vereenigde Staten per spoor werden doorkruist. De booten der Indische maatschappijen bepaalden zich tot de vaart tusschen Frisco en de Oost-Indische havens, terwijl de reizigers naar New-York werden gebracht door schepen der Holland-Amerika-lijn.

Ook de directe route naar West-Indië was verlaten. De Koninklijke West-Indische Mail liet de Oranje-Nassau tusschen West-Indië en New York heen en weer trekken.

Het was in het begin van het jaar 1918, dat de Nieuw-Amsterdam zou vertrekken en, als ik mij goed herinner, waren de passagiers omstreeks negen uur in den avond van den 15en Januari aan boord verzocht.

In Rotterdam was het dien geheelen dag merkbaar geweest. Op straat en in de koffiehuizen heerschte eene ongewone en zenuwachtige drukte. Een vertrekkend passagiers-schip was geen ge-

$$
-225-
$$

West-Indische Gids XIX 
woon verschijnsel meer, en dat een zeereis niet geheel gevaarloos was, hadden de Statendam en de Rijndam ondervonden. De aanstaande passagiers werden dus door vele vrienden en familieleden vergezeld, en daar men zich toch niet aan verdrietige overwegingen kon overgeven, was de stemming in de stad overdreven vroolijk en nerveus.

Het komen aan boord was weer eens eene geduldoefening. Vanwege de Maatschappij en het Amerikaansche consulaat werden de biljetten, passen en visa zeer nauwkeurig gecontroleerd. Ook het bekomen dier visa was al eene niet eenvoudige zaak geweest, die een paar dagen wachten in eene file in den tuin van het consulaatsgebouw - het was November - hadden gevorderd.

Het zal dus zoowat half twaalf geweest zijn, toen wij eindelijk aan boord kwamen. Hier: de gewone atmosfeer van een vertrekkend schip, dat zich vult. Heel erg vult. Het schip, dat eigenlijk bestemd was voor een 250 -tal eerste klasse en even zoovele tweede klasse passagiers, was nu ingericht voor ruim het dubbele van dit aantal. In de derde klasse reisden slechts enkele militairen.

Mijne jonge vrouw en ik waren ingedeeld in diepgelegen en kleine vier-persoons-hutten, die niet al te ver van elkaar waren gelegen. Bij elkaar in één hut blijven was slechts aan enkele uitverkorenen beschoren en zeker niet aan een stel jeugdige gouvernementspassagiers zonder reis-ervaring.

We gingen dus, ieder in onze eigen hut, slapen met paraat gehouden zwemvest. En na een verdacht rustige nacht keken we den volgenden morgen uit de patrijspoort, verwachtende de wijde zee te zullen zien. Dat viel tegen, want wat we zagen was de Rotterdamsche kade: het schip was niet vertrokken. En het bleek dat we ook dien dag en nog vele dagen daarna aan de kade zouden blijven liggen. Er scheen iets met de papieren niet in orde te zijn, doch wat dit was, werd niet bekend gemaakt.

Dag voor dag was nu ieders hoop, dat het eindelijk gebeuren zou. De Amerikaansche consul liet bekend maken, dat hij niet voor de geldigheid van het visum kon instaan, als men van boord ging. Toch waagden enkelen het er op. Maar des nachts was iedereen weer terug Het werd een speciaal tochtje voor de Rotterdammers om met het veerbootje, dat vlak vóór de ligplaats van de Nieuw-Amsterdam passeerde, over te steken en dan naar vrienden en bekenden aan boord te wuiven. En van boord werd dat met de gebruikelijke gekruide humor beantwoord. Aan boord komen van niet-passagiers werd niet toegestaan.

De bekende Hollandsch-Amerikaansche schrijver Hendrik 
Willem van Loon was onze medepassagier, en hij gaf uiting aan zijn humor in den vorm van allergeestigste teekeningen, die voor het aanplak-bord een geregeld gedrang veroorzaakten. Ik herinner me er een, voorstellend de Nieuw-Amsterdam over 50 jaren, nog steeds voor den wal liggende, geheel bedekt met spinnewebben, waartusschen de passagiers met lange, witte baarden. Deze teekeningen werden later bij opbod voor een liefdadig doel verkocht, waarbij ze nog een vrij groot bedrag opbrachten.

Daar er slechts weinigen waren, die aan den wal durfden te gaan, was het in alle salons overvol. Wie eenmaal een plaats veroverd had, stond maar niet weer op, want dan had hij den verderen ochtend of middag geen kans meer, en moest hij maar op het dek of in zijn hut blijven. Het dek was echter in Januari geen ideale verblijfplaats.

In de eetzaal werd in twee ploegen gedineerd. De minder goede hoedanigheden van zijn mede-passagiers kan men op zoo'n volle boot uitnemend leeren kennen. Als de koffie of thee gebracht werd, werden de stewards bestormd en ieder, die wat veroveren kon, nam twee of drie keer zijn portie en voor de minder vechtlustigen bleef meestal niets over. In de waschplaatsen moesten de kleine, losse handdoekjes, wegens overmatige diefstal, vervangen worden door groote handdoeken, die goed vastgelegd waren. Ik herinner me een passagier, die de reis met een blauw oog heeft moeten doen wegens een vechtpartij, met mevrouw als inzet. Ook werd er geregeld wit brood naar den wal gesmokkeld, wat verboden was, omdat men dat bakte van meel, dat uit Amerika was meegebracht, speciaal ten gerieve der passagiers. In $\mathrm{Ne}-$ derland bestond toen al lang geen wit brood meer. Trouwens brood kon daar niet dan op broodkaarten worden verkregen. Een der laatste dagen werd de meel-voorraad dan ook door de douane verzegeld.

Dit alles geschiedde in de eerste klasse. Gelukkig kwam aan deze gedwongen werkloosheid een einde. Op 24 Januari werd bekend gemaakt, dat thans de papieren in orde waren en dat het vertrek op den volgenden dag was bepaald. Voor dezen laatsten dag werd aan passagiers toegestaan toch nog aan wal te gaan.

En werkelijk op Vrijdag den 25en Januari, in den vroegen namiddag, doordreunde het zware vertreksein het schip en de touwen werden losgegooid. Door sleepbooten werd het groote schip op stroom gebracht. De tocht langs de Maas en den Nieuwen Waterweg geschiedde onder groote belangstelling van geheel Rotterdam. Dichte hagen menschen stonden langs de kaden om ons te 
zien vertrekken. Des avonds werd eindelijk de volle zee bereikt.

We werden geëscorteerd door twee sleepbooten. Als er iets gebeurde, waardoor het schip de reis niet kon vervolgen, zouden zij de passagiers moeten overnemen en in veilige haven brengen. Het mijnen-gevaar was in de Noordzee in die dagen lang niet denkbeeldig. Tegen gevaar van torpedeeren door een duikboot zullen we wel verzekerd zijn geweest, en misschien is het lange wachten wel geschied om zeker te zijn dat alle duikbootcommandanten voldoende gewaarschuwd waren.

Dien nacht werden door een ieder de zwemvesten weer gereed gehouden. Velen brachten den nacht in een der salons door, en wie te bed ging ontkleedde zich zoo weinig mogelijk. Toen de dag aanbrak waren we al een heel eind van huis, al waren de eenige schepen, die we hier passeerden, nog steeds Hollandsche visschers. In den nacht was halve kracht gestoomd om de sleepbooten niet te ver achter te laten, doch thans voer de NieuwAmsterdam met een flinke vaart, zoodat de sleepbooten weldra aan den gezichtseinder verdwenen.

Dien morgen beleefde de Nieuw-Amsterdam, hier nog een korte sensatie. We voeren in Noordelijke richting, want we moesten om de Noord van Schotland heen, en het zal op de hoogte van het Skager Rak geweest zijn, dat er aan den Oostelijken gezichtseinder een drietal schepen werden gezien. Aan de scherpe contouren waren duidelijk oorlogsschepen herkenbaar.

Onmiddellijk was aan boord van de Nieuw-Amsterdam alles in rep en roer. Iedereen was aan dek en alles wat aan boord zich eenigszins autoriteit voelde, klom naar de brug, waar de kapitein door een kijker de situatie stond op te nemen. Onder de passagiers ontstond de vrees, dat het Duitsche oorlogsschepen waren en we nu wel opgebracht zouden worden naar Bremen of naar Hamburg. Dat gebeurde in dien tijd wel meer. De stemming werd dus hoe langer hoe gedrukter.

Plotseling zagen we, dat een der schepen zich uit het kluwen los maakte en met groote snelheid op ons toevoer. Het was een prachtig gezicht, dat ranke, snelle schip, dat golven van schuim voor zich uit joeg. De spanning bij ons aan boord groeide met het naderen van den jager en de stilte was tot materie geworden. Toen het Oorlogsschip ons tot op enkele honderden meters genaderd was, ontdekte iemand de vlag. Deze was.... Engelsch. De zucht van verlichting, die toen opsteeg van de verzamelde passagiers der Nieuw Amsterdam moet, dunkt mij, op het andere schip haast waarneembaar zijn geweest. Plotseling was de stemming ge- 
keerd, men praatte weer, wees elkaar op details, en.... men lachte weer.

De Engelsche torpedojager maakte in volle vaart de bocht, schoot langs ons heen. De matrozen joelden en zwaaiden met hun hoofddeksels. Weer zwaaide het schip, en in dezelfde vaart, als het gekomen was, verwijderde het zich, tot het zich weer bij de beide anderen gevoegd had.

De Nieuw-Amsterdam, die vaart geminderd had, stoomde nu weer in volle vaart naar het Noorden. In de verte waren zoo nu en dan de vage omtrekken van een enkele rots van de Noordsche kust te zien, waarachter de fjorden te raden waren. En daarna bogen we naar het Westen en later naar het Zuiden, en toen voelden we New York al nader komen.

De sleepbooten hadden ons al lang verlaten. Hier scheen het gevaar voor mijnen en onderzeeërs niet zoo groot meer. In de Noordelijke IJszee hadden we nog een flinke storm te doorstaan, die dwars op het schip scheen in te komen. We rolden hevig, de stormlatten kwamen op de tafels en de eetzaal was plotseling niet te klein meer.

Toch verliet ook onder die omstandigheden de geest van onbescheidenheid sommige passagiers niet, en wij betrapten herhaaldelijk een dame er op, dat zij, soms ten koste van hare tafelgenooten, dubbele porties nam van vruchten of dessert, zoogenaamd voor haar zeezieke echtgenoot, terwijl later bleek, dat deze aan dek volop van alles bediend werd. Ik heb mij vaak in binnen- en buitenlandsche hotels en aan boord van verschillende schepen geërgerd over de onnoozele onbescheidenheid van een bepaald soort landgenooten. Zij schijnen te vreezen, dat hun anders te kort gedaan zal worden. Doch zelven doen zij te kort aan onze goede naam. Zij zijn oorzaak dat hoteliers genoodzaakt zijn vele faciliteiten te laten vervallen.

$\mathrm{Na}$ den storm kwam een zeer felle koude, zooals die aan de Oostzijde van den Atlantischen Oceaan onbekend is. Ik herinner me niet meer, hoe laag de thermometer wel stond, maar het was laag. Aan dek kon men bijna niet meer verblijven en de salons raakten weer overvol. Toen we in New York aankwamen, moet de Nieuw-Amsterdam het schip van den ijskoning geleken hebben.

Ik meen, dat de zeereis 12 dagen geduurd heeft, en het zal de 6e Februari 1918 des avonds omstreeks 9 uur geweest zijn, dat de Nieuw-Amsterdam onder het uitstooten van eenig vreugdegebrom in de baai van New York ten anker ging. In de verte waren millioenen lichten van de wereldstad te zien. 
Dien avond gebeurde er niets bijzonders meer, behalve dan dat we hevig door zoeklichten werden beschenen, en dat er een kleine militaire bewaking aan boord kwam. Aan boord heerschte de vroolijkheid van de spoedig verwachte aankomst, doch van aan wal gaan was geen sprake.

Het was jammer, dat er den volgenden morgen een dichte mist hing. Reeds vroeg stoomden we op, doch van de beroemde skyline waren slechts vage contouren te zien. En het Vrijheidsbeeld was groot maar wazig. Toch maakte het opstoomen door de ontzag'lijke scheepvaartdrukte en toch ook wel door de spookachtige omtrekken der onwaarschijnlijke sky-scrapers een onvergetelijken indruk.

Omstreeks acht of negen uur kwam een douane-bootje langszij en klommen een twintigtal functionarissen aan boord, waaronder vele vrouwelijke. Allen waren in keurige khaki-uniformen gekleed. Op het dek bij de uitgangen namen enkele lagere ambtenaren plaats, en de anderen verdeelden zich over de salons. Waar en hoe de passagiers moesten wachten, was toen verder bijzaak. Toch duurde dat nog lang genoeg. Ook hier speelden ondervinding en ellebogen een groote rol.

Het zal zoowat drie uur in den namiddag zijn geweest, toen mijne vrouw en ik aan de beurt kwamen. We werden voor een der tafels in de eetzaal gebracht, waar onze passen werden nagezien en waar ons allerlei vragen gesteld werden. Toen bleek, dat ik een week of twee vóór het uitbreken van den oorlog voor korten tijd in Duitschland en Oostenrijk was geweest, mochten we weer wachten, thans in de social hall. Eindelijk werden we voor een tafel geleid, waar het ondervragen opnieuw begon. Thans waren het blijkbaar hoogere immigratie-ambtenaren en militairen. Er was een jeugdig militair bij, die uitnemend Hollandsch sprak en die als tolk fungeerde. Blijkbaar bleek hier onze onschuld aan eenigerlei spionnage zonneklaar. Althans we mochten eindelijk vertrekken, en omstreeks zes uur stonden we in een groote douaneloods te Hoboken. Onze koffers waren daar ook en de visitatie was nu spoedig verricht. Nu waren we vrij en konden de stad ingaan.

Ik zal hier geen beschrijving geven van New York, noch van de enkele tochtjes, die wij in den omtrek maakten. Dit alles is reeds vaak genoeg beschreven. Als normale toeristen logeerden we in een der uitstekende hotels en wel niet in het toen zeer in trek zijnde hotel MacAlpin, waar de overgroote meerderheid van onze medepassagiers hun intrek hadden genomen. Het is genoeg bekend, dat New York, al noemt de Amerikaan het dan de minst 
Amerikaansche stad van de States, voor den Europeaan toch voldoende verschilpunten biedt, om een verblijf van eenige weken aldaar in voortdurende ver- en bewondering te kunnen doorbrengen. Dat het land in oorlog was, kon uit directe ontberingen niet blijken, daarvoor was men te ver van het krijgstooneel verwijderd. Wel bestonden er „Wheatless” en „Meatless days”, doch als vreemdeling merkte men daarvan niet veel. In de koffiehuizen en restaurants bestond meer dan gebruikelijk enthousiasme voor de „Star-spangled banner”, en vaak kwam men in de stad wagens tegen, waarin een „band” zich had opgesteld, die de „The Yanks are coming" speelde, waarna een onderofficier een toespraak tot het verzamelde volk hield en trachtte vrijwilligers te werven om naar "Over there" te gaan. In het algemeen was New York in die dagen vol leven en ook, misschien met onderdrukking van edeler gevoelens, vol vroolijkheid.

De Volstead-act was in Februari 1918 nog niet van kracht. Toch viel het ons op, dat er in restaurants aan tafel veel minder wijn en bier gedronken werd dan in overeenkomstige gelegenheden in Europa. Blijkbaar waren de "saloons" de grootere zondaren op dit gebied. Later toen er de prikkel van de verboden vrucht was, schijnt dat anders te zijn geworden, doch bij ons bezoek dronken de meeste gasten der midden-klasse restaurants ijs-water aan tafel.

Behalve de gewone voorbereidingen, als bezoeken aan consulaat, customhouse en scheepsagentschap, waren er geen formaliteiten te vervullen. Het spande in die dagen voor de Hollandsche schepen, die in de Amerikaansche havens aanwezig waren. Vertrek van schepen had niet geregeld plaats. En ook naar Curaçao was het aantal afvaarten van Hollandsche booten zeer sporadisch.

Wel vervulden de Red-D-booten van Philadelphia uit geregeld hunne diensten, doch als gouvernements passagiers was ons voorgeschreven per Koninklijke West-Indische maildienst te reizen. Het duurde tot begin Maart, vóórdat een boot van dien dienst vertrok. Dat zou de Oranje-Nassau zijn.

Alles was in orde en de 2e Maart om 12 uur in den middag zouden we vertrekken. De le Maart brachten we dus onze koffers naar boord in Brooklyn. Daarbij deed zich een klein incident voor dat kenmerkend was voor de, naar Europeesche gedachten, wat naïeve gevoelens van den doorsnee-Amerikaan uit die dagen. De Amerikanen zijn een volk van heterogenen oorsprong, doch bij de geboren Amerikanen was in het begin van den oorlog een 
vaderlandsliefde ontstaan, die ons overigens ten voorbeeld kon strekken.

Ik had namelijk verzuimd de enkele boeken, het was wat ontspanningslectuur en verder nog wat plaatsbeschrijvingen, aan het custom-house op te geven. Eigenlijk mocht het dus niet uitgevoerd worden, ik denk ook als maatregel tegen spionnage, doch daar het geheel niet zoo bijzonder waardevol was, had ik het er maar op gewaagd. Toen we aan boord kwamen, moesten onze koffers door de douane worden onderzocht. Direct werden de boeken ontdekt, en de Amerikaansche ambtenaar trok een zeer bedenkelijk gezicht. Toch ging hij eens kijken wat het voor lectuur was, dat zoo'n Hollander meenam. Al spoedig sloeg hij aldus een bandje open, dat „America, the land we love" heette. Door die titel was hij blijkbaar zoo in zijn zwak getast, dat hij van alle verdere onderzoek afzag en wegging met den raad die boeken tot aan het vertrek maar wat achteraf te houden.

We hebben verder nergens last mee gehad en Zaterdag de $2 \mathrm{e}$ Maart is de Oranje-Nassau werkelijk vertrokken. De geruchten over confiscatie der Hollandsche schepen liepen toen reeds. Op dien dag was het overigens nog vrij koud, maar onze koers was naar het Zuiden. Weldra werd de beruchte Kaap Hatteras gepasseerd. Tusschen de Bahama's voeren we door en onze eerste haven was Port-au-Prince, waar we aan een betonnen steiger konden meeren.

Port-au-Prince stond toen onder sterken, Amerikaanschen invloed, doch in naam was Haiti nog een onafhankelijke negerrepubliek. Als eerste tropische haven was het bezoek voor ons natuurlijk eene belevenis. Het geschreeuw en de drukte van het zwarte volkje op de markten, de luide alleenspraken van vrouwen met zware lasten op hoofd, de hevige gesticulaties - we hebben het alles later herhaaldelijk gezien, doch hier waren het eerste indrukken. En in de volgende Haïtiaansche havens, waar we op de reede bleven liggen, was het een vermaak het luide getwist te hooren, waaronder ze elkaar op overigens vriendschappelijke wijze vrachtjes trachtten af te snoepen.

$\mathrm{Na}$ Port-au-Prince vervolgden we onze kustreis naar CapHaïtiën, de oude nederzetting van Columbus, naar Aux Cayes, met zijn tropische palmenkust, en naar Jacmel, waar men het puikje van de rhum kon krijgen. In al deze havens was men blij ons schip te zien, want schepen zag men er sinds den oorlog niet zoo veel meer.

Heel lang vertoefden we overigens nergens, en na een goede 
week zwervens langs de kust van Haïti, vervolgde de OranjeNassau zijn reis naar Curaçao. Voor ons waren die tropennachten aan boord met zijn schitterende sterrenhemel een verrukking. Voor het eerst zagen we het Zuiderkruis. Maar ook de Groote en de Kleine beer en, zooals de scheepsjongen ons toevertrouwde, „,allemaal kleine beertjes”, vertoonden zich aan ons leeken-oog.

Ik weet niet meer precies op welken dag we Willemstad bereikten, maar het was na het midden van Maart 1918. De geheele nacht hadden we langs de Zuidkust van het „Masja doesji eilàndsje" gevaren en vroeg in den ochtend kwam de haven in zicht.

U hier eene beschrijving geven van Curaçao, zou zijn uilen naar Athene dragen. Door kundiger geest en door kunstvaardiger hand zijn aan die schoone koloniale parel in het Nederlandsche snoer vele bladzijden gewijd. Ik kwam er ten slotte als ingenieur, en het lag voor de hand, dat de technische vraagstukken mij het meest behoorden te interesseeren. Daarom even een kort woord, voor zoover die vraagstukken van algemeen interesse kunnen worden geacht.

De toenmalige Gouverneur Nuyens had de verbetering van den Curaçaosche havenmond weten door te voeren. Vroeger waren bij de uitvoering van dat werk groote moeilijkheden gebleken. Men had een kleine zandzuiger laten uitkomen, maar deze bleek niet te voldoen. Doch de waterstaatsingenieur Ir. Ph. van der Breggen, die toentertijd de functie van directeur van openbare werken vervulde, liet het vaartuig ombouwen tot werkschip voor rotsboringen. Langszij was gelegenheid om ondiepe boringen in den uit koraalrots bestaanden havenbodem te verrichten. In de boorgaten werden door duikers, met helm, doch zonder verder duikerpak, dynamietpatronen aangebracht en toegestopt. Van den wal af werden dan die patronen langs electrischen weg tot springen gebracht, en het verbrijzelde bodem-materiaal werd door een grijper verwijderd.

Het was eene methode, die een meer dan gewone mate van taaiheid en doorzettingsvermogen van den directeur en van zijn helpers vorderde, en die eerbied afdwong. Het werk werd tot een goed einde gebracht. Het was in Maart 1918 reeds voor een groot deel gereed en in de stad was men geheel gewend aan de dagelijksche doffe knallen der dynamiet-ontlading.

Behalve het vraagstuk van den havenmond, was er nog een verder reikend vraagstuk van de verbetering van de haveninrichting. Bekend zijn de Curaçaosche „werven" (,wharfs") langs de St. Anna baai, zeer eenvoudig ingerichte aanlegplaatsen, zon- 
der veel outillage of accomodatie. In het achterliggende Schottegat bestond vóór de werken van de Bataafsche Petroleum Maatschappij zoo goed als heelemaal niets. In 1915 was het Panamakanaal geopend en, evenals vele andere West-Indische havens, hoopte Curaçao daarvan voordeel te zullen ondervinden.

Natuurlijk had men op Curaçao met het maken van plannen niet gewacht tot het Panamakanaal gereed was. Het was de Commissie voor de Handelspolitiek, die de behoefte aan eene dieper gaande bestudeering van dit vraagstuk had gevoeld en onder hare auspiciën had de toenmaals reeds bekende havendeskundige, de civiel-ingenieur Jhr. O. C. A. van Lidth de Jeude een uitvoerig en belangrijk rapport opgesteld, waarin de zaak van technische en economische zijde werd bekeken.

Ook prof. dr. ir. J. Kraus had bij zijn laatste reis naar ZuidAmerika Curaçao bezocht, waarbij verschillende onderdeelen van het havenplan aan zijn oordeel waren onderworpen. In zijn gezelschap bevond zich mede Ir. G. J. van den Broek, die daarover een rapport schreef, dat gedateerd is December 1914.

Behalve vele bezoeken aan verschillende deelen van het eiland, was het vooral de studie van deze rapporten, die mij gedurende ons eerste verblijf op Curaçao bezig hield. Mijn hoofdopdracht was de mogelijkheid te onderzoeken voor den aanleg van eene aanloophaven op St. Martin en uiteraard was het op Curaçao verzamelde studie-materiaal daarvoor van groot belang.

Nauw verwant aan de havenplannen was het watervraagstuk. Curaçao is zeer droog, doch, afgezien daarvan, zal op elk klein eiland het vinden van eene goede prise-d'eau een moeilijkheid zijn en voor St. Martin zou dit zeker even goed gelden.

Een aardige oplossing voor Curaçao was ontworpen door Ir. van Lidth de Jeude, die een onderaardsch dal op de plantage Muizenberg - aan de overzijde van het Schottegat gelegen door een cementen dam geheel wilde afsluiten en er aldus een waterdichte kom van wilde maken. Die dam zou ter weerszijden in de onverweerde diabaas moeten reiken. Voor het maken van den dam werd gedacht aan een cementeermethode, zooals bij het cementeeren van petroleum-bronnen gebruikelijk is, en waarbij de cementmelk in de aarde wordt ingeperst.

Behalve dit plan, was er ook nog een plan van Prof. Ir. Weys, die naar een nog gunstiger plaats gezocht had en die meende gevonden te hebben in de plantage Mount-Pleasant. Hier waterde een grootere kom door een nauwe hals naar zee af. Door middel van een kortere onderaardsche dam zou dus een grooter reservoir 
ingesloten kunnen worden. In tegenstelling met de Muizenberg was de plantage Mount-Pleasant evenwel toenmaals van groote waarde, wijl hier eene sisal-aanplanting was tot stand gebracht. Ook zou de buisleiding naar de stad veel langer moeten worden, dus kostbaarder.

Deze vraagstukken stonden in 1918 in het brandpunt der belangstelling. Verder was er een begin gemaakt met den bouw van de nederzetting der Bataafsche Petroleum-maatschappij, die hare Curaçaosche belangen in de Curaçaosche Petroleum Industriemaatschappij had ondergebracht. Natuurlijk had ook die maatschappij groot belang bij eene goede haven-outillage en zij was, dan ook bezig met den aanleg van eenige steigers in het Schottegat.

Onder het bestudeeren van al deze, met mijne opdracht verwante, aangelegenheden naderde het tijdstip van het vertrek van de paketschoener „Estelle”, die ons naar St. Martin zou brengen. Ik had al eens een bezoek aan boord gebracht, en de accomodatie was daar zoo verschillend van het verblijf aan boord der schepen, waarop wij tot dusver gevaren hadden, dat ik het beter vond mijne vrouw daarover maar niet al te nauwkeurig in te lichten: alles bij elkaar zouden we toch wel eenige weken aan boord moeten blijven, en het mòest nu eenmaal, dus waarom te voren daarover zorgen te maken.

De Estelle was een echte Curaçaosche schoener, een uitermate elegant vaartuig en een snelle zeiler. Het laadvermogen bedroeg 165 bruto-registerton. Wanneer het witte scheepje onder volle zeilen lag was het voor degene, die het van buiten zag een verrukking voor het oog. Het verblijf aan boord van zulk een betrekkelijk rank vaartuig met slechts zeer primitieve passagiersruimten voorspelde evenwel geen onverdeeld genoegen te zullen zijn.

$\mathrm{Na}$ een verblijf van bijna twee maanden in de ons met groote gastvrijheid ter beschikking gestelde woning te Scharloo scheepten wij ons den 10en Mei in den laten namiddag in en, zooals ik gevreesd had, was onze hut voor mijne vrouw een groote tegenvaller. Met groote sportiviteit heeft zij zich evenwel daarover heengezet, alleen maar wenschende dat „het al maar vast herinnering”" zou zijn.

Bij het ongemak, dat onze hut op zich zelf reeds bood, kwam nog, dat wij haar zouden moeten deelen met eene St. Martinsche dame met twee kleine kinderen. Eenige dagen vóór het vertrek van de Estelle had ik namelijk bezoek van deze dame gehad, die 
mij mededeelde, dat het scheepje geheel vol was en dat zij toch wel erg graag met deze laatste reis vóór de orkaanmaanden wilde meegaan. Haar zuster was op Aruba overleden en had twee kleine kinderen achtergelaten, waarmede de vader eigenlijk niet veel raad wist. $Z$ ij had dus de zorg van de kinderen op zich genomen, en wilde nu met hen naar de grootouders op St. Martin vertrekken. Haar eenige kans was, dat ik haar toestond het derde bed in onze hut te betrekken. Ik vond dat met mijn Europeesche denkbeelden een eenigszins vreemd verzoek, doch later is mij gebleken, dat ik mij daarin totaal vergiste. Toen wij aan boord kwamen had zij met de beide kinderen bereids beslag gelegd op het, in de hut aanwezige, breede bed. Ik heb niet gezien, dat zij daarvan ook maar één moment is opgestaan, vóór wij St. Thomas bereikten. En veel woorden behoefden wij niet met elkaar te wisselen, dat werd niet verwacht, en daartoe waren wij trouwens niet in staat wegens onzen gezondheidstoestand in het schommelende schip. Overigens heeft de deur van onze hut gedurende de geheele reis open gestaan en behalve de eerste paar uren van den eersten nacht en gedurende de paar laatste nachten van ons verblijf op de Estelle hebben we onze beide smalle, boven elkaar gelegen kooien slechts gebruikt voor het bergen van bagage.

De geheele eerste-klasse-slaapruimte bestond overigens behalve uit onze hut uit een tweede, die het spiegelbeeld daarvan was, en uit de vier kooien in de kajuit-eetzaal, waarop beide eerstgenoemde hutten uitkwamen. Daar het schip ditmaal overvol was, was ook nog een bank in de eetzaal opgesteld, die als bed was ingericht, en verbleef de heer van der Breggen, die de reis medemaakte, in de hut van den schipper. Aldus waren er een vijftiental „Europeanen" ondergebracht en, zooals 's lands gebruik was, daartusschen door sliepen op den grond nog eenige vrouwelijke negerbedienden, die in de nabijheid harer meesteressen moesten blijven. Niet het minst aan deze laatsten was het te danken, dat er een lucht in het geheele verblijf hing, die mij sterk aan aloë deed denken.

Uitgeleid door verschillende kennissen, die wij inmiddels gemaakt hadden, gingen wij dus dien 10en Mei aan boord, en weldra zwaaide de oude, niet fraaie, maar toch zoo practische, Emmabrug voor ons scheepje open. De touwen werden losgegooid, en het duurde niet lang, of wij waren weer in het ruime sop, nu daar heel wat dichter bij dan op de Oranje-Nassau, waarvoor we na de Nieuw-Amsterdam toch al zoo onzen neus hadden opgehaald.

De eerste paar uur was alles heerlijk, ten minste nadat de soep, 
waarin kakkerlakken-pootjes dreven, genuttigd was. Na onze kennismaking met de tropische hitte was het verblijf, dezen eersten avond op zee, een verrukking, zoolang we nog onder de bescherming van het eiland voeren. Doch toen we in onze kooi waren gekropen, kwamen we onder Curaçao vandaan en nu leek het wel of schip, stroom en wind, allen in verschillende richting wilden en of wij vlak bij den waterspiegel als wilden in 't rond tolden. Of het dien nacht harder woei dan gewoonlijk, weet ik niet, doch wel weet ik, dat we nog nooit zoo zeeziek zijn geweest. Ook later niet. Midden in den nacht zijn we opgestaan en zijn we, struikelende over, op den vloer liggende, negerinne-beenen naar dek gestrompeld, waar we neervielen op het eerste het beste voorwerp, waarop gezeten kon worden. De rest van den nacht heeft mijne vrouw doorgebracht gedeeltelijk liggende in een "dog-house", een soort overdekte stuurmanskooi, die nabij het roer stond. Hare voeten werden voortdurend door buiswater overspoeld. Wat mij betrof, ik liep, of zat, of lag, op een tros of op een ander voorwerp, zoo ziek als een hond, in berustende afwachting van het einde dezer kwelling.

Gelukkig heeft die niet lang geduurd. Reeds vroeg in den ochtend bereikten wij de reede van Bonaire en konden wij tenminste even vasten grond onder de voeten voelen. Vóór den middag waren we alweer zeilende.

Van Bonaire af werd koers gezet naar St. Thomas. Het ging dus onder een vrij scherpen hoek tegen de richting van een sterke passaat in. Met groote slagen werd gelaveerd en elk overstag gaan wierp ons vrijwel onderste boven. Want we hadden een definitief verblijf aan dek gekozen. In onze hut bleek de atmosfeer niet houdbaar; dus zochten we maar elders een onderkomen. Het dek stond geheel vol met kisten, en daar bovenop was wel een plekje te vinden voor twee personen: een hoogere kist onder het hoofd, dan een kist die geen verdieping meer vertoonde vóór ter hoogte van delendenen, en wat er ten slotte onder de beenen kwam, kwam er minder op aan. De kisten waren afgedekt door een zeil, wat de scherpe randen verzachtte. En van den kapitein hadden we een paar dekens gekregen want de warmte viel des nachts niet mee. Overdag konden we wel eens even rondloopen, doch de nachten brachten we verder tot St. Thomas op ons plekje aan dek door. Gelukkig heeft het al die dagen niet geregend. Maar toch werden we wel nat, want, ofschoon we vrij hoog, bovenop de deklast, lagen, zoo nu en dan spatte er een brekende golf over ons heen en een paar malen per nacht werden we aldus door een plons 
water in ons gezicht gewekt. Doch de rest van de nachten was het heerlijk en genoten we van het maanlicht, dat in den tropennacht scheen met een helderheid, die in Europa alleen in enkele vriesnachten geëvenaard wordt.

Natuurlijk was er van uit de kleeren komen in de zes dagen, dat de reis tot St. Thomas duurde, geen sprake. En toen we daar aankwamen voelden we ons in een onbeschrijflijk onaangenamen toestand. Bovendien waren door al die nachten aan dek en door het overplonzende water onze gezichten dermate gezwollen, dat de oogen niet meer waren dan kleine spleetjes. Ik geloof, dat de Amerikaansche douane-ambtenaren in St. Thomas ons met eenig wantrouwen aanzagen. Althans het eischte eene breedvoerige uitlegging, hoe het mogelijk was dat we er zoo uitzagen. Na eenig praten, bleken deze mannen evenwel uitermate welwillend en, voorzien van veel goede raad, mochten we aan den wal gaan, waar een verfrisschend bad in het hotel, schoone kleeren en eene wassching onzer gezichten met „lime"-sap wonderen verrichtten. Toen we dus na een uurtje aan tafel zaten op de galerij van ons, aan de baai gelegen, hotel konden we weer van het heerlijke, jonge leven genieten.

St. Thomas zal in die dagen zoowat een jaar onder de vlag van de Vereenigde Staten zijn geweest. Het Amerikaansche bestuur had de functies der Denen overgenomen, was in de Deensche gouvernementsgebouwen gevestigd en was bezig Amerikaansche gewoonten, soldaten en handelswaren in te voeren. De laatsten waren er eigenlijk altijd al geweest, net als in de rest van WestIndië, doch de Amerikaansche marinesoldaten waren nieuw en wat de Amerikaansche gewoonten betrof, daaraan moest men nog wat wennen. Want in West-Indië wordt niet zoo op een klein beetje kleur gelet en de Amerikanen deden dat sterk. Hier en daar was er dan ook wel iets merkbaar van een kleine kater na de roes der eerste vreugde. Daaraan zal men evenwel later wel gewend zijn, en een voorbeeldig Amerikaansch bestuur zal ongetwijfeld zijne zegeningen hebben doen kennen.

In het Deensche St. Thomas van vóór den wereldoorlog waren sterke Duitsche scheepvaartbelangen vertegenwoordigd geweest. De Hamburg-Amerika-lijn had er eene nederzetting gehad, doch deze had natuurlijk in 1918 niet veel meer in te brengen en toen wij in Mei van dat jaar St. Thomas bezochten, waren de fraaie gebouwen door den dienst der haven-aangelegenheden in gebruik genomen. Aan het hoofd daarvan stond een Amerikaansche ingenieur, die de uniform droeg van marine-officier. Ook de steigers 
en verdere inrichtingen der Hamburg-Amerika-lijn waren door den Staat geconfisceerd.

We hebben ongeveer een week in St. Thomas doorgebracht, en na afloop onzer werkzaamheden hebben we genoten van de fraaie, tegen een drietal heuvels gebouwde, hoofdstad CharlotteAmalia. Eigenlijk bevonden zich nog eenige uitloopers van de stad op twee andere heuvels, en deze vijf heuvels lagen als een coulisse vóór de hoogere bergen op den achtergrond. Op den Zondagmorgen maakten we eene wandeling tegen de steile hellingen der hoogere bergen, en op de kam hadden we een fraai uitzicht naar de Caraïbische Zee eenerzijds en naar de zijde van den Atlantischen Oceaan anderzijds. Bij het bedenken, dat aan de andere zijde van dien Oceaan Europa was gelegen, kregen we het gevoel toch niet geheel in een vreemde wereld te zijn.

Naast de fraaie palmen-groepen waren het vooral de flamboyants, de pigeontree's met hunne groote roode en witte bloemen, en de bougainvilla's, die we hier voor het eerst in grootere hoeveelheden zagen, die op ons een onuitwischbaren indruk maakten.

Ofschoon onze werkzaamheden reeds na een dag of vijf beeindigd waren, kon de „Estelle” niet eerder vertrekken dan Donderdag $23 \mathrm{Mei}$, omdat het in orde maken der papieren, - ik meen me te herinneren dat Washington of een ander hoofdkwartier zijn toestemming moest geven - niet eerder gereed was. Het wachten was hier overigens geenszins onaangenaam en toen we dan na onze week verblijf op St. Thomas de baai van Charlotte-Amalia weer uitzeilden, waren we volkomen bekomen van zeeziekten en andere kwade gevolgen der zeereis. De nachten brachten we maar niet meer aan dek door, en na twee nachten en één dag kwamen we voor de Ladderbaai van Saba ten anker.

Meestal varen de schepen, die Saba aandoen, naar de Fortbaai, doch als er daar een te sterke deining staat, wegens den harden wind, wordt de Ladderbaai opgezocht. Men landt dan voor een bijna loodrechte rots en men vraagt zich af hoe men daartegenop komt. Bovendien is dat landen niet zoo heel gemakkelijk. De schoener moet eenige honderden meters uit den wal blijven liggen, en men moet dus in een roeiboot overstappen, die door eenige Sabanen naar het, op de reede liggende, schip is geroeid. Dat is niets bijzonders, want zoo moet men in vele havens, en bijna in alle West-Indische, aan den wal komen. Doch op Saba staat er in de onmiddellijke nabijheid van de kust een hevige branding en daar moet men doorheen, bij voorkeur zonder nat te worden. De Sabaansche roeiers stappen vóór het begin van de 
branding snel uit, wachten op de eerste breker, en duwen op den top van die golf de boot met groote handigheid op den oever, die hier uit rolsteenen bestaat.

Als men dan op den wal staat, ontdekt men een pad, dat in de rots is aangebracht en dat niet veel meer is dan een soort trap of ladder. Toch zien de kleine Sabaansche paardjes kans om daar tegenop te komen zonder over rollende rotsblokken te struikelen of van steile rotswanden af te vallen.

Om aan het eerste dorp, The Bottom, te komen, moesten we ruim 200 meter zeer steil klimmen. Daar er oudere passagiers waren, en slechts een beperkt aantal paardjes naar het strand was afgedaald, begonnen wij den voettocht naar boven vol moed, doch we waren blij toen de paardjes ons halverwege weer tegemoet kwamen.

Ook hier wil ik niet in eene plaatsbeschrijving vervallen. Elders is Saba beschreven, het kleine eiland, dat als een $900 \mathrm{~m}$ hooge, massale piek uit zee oprijst. We bezochten Windwardside en St. John en de „Sulfur-mine”, alles te paard, en we beleefden er een sensatie van groote en eenvoudige schoonheid. In „The Bottom" hebben we een paar nachten gelogeerd bij de echtgenoote van den kapitein van een vijfmast-schoener, die met Amerikaansche lading voer. Een paar maanden later hoorden wij van het vergaan van dien schoener, en wij dachten met weemoed aan de jonge weduwe, die ons verblijf op Saba tot iets zoo prettigs had gemaakt.

Op geen van onze andere eilanden is een zoo krachtig en zuiver blank ras blijven bestaan als op Saba. Het is waar, op St. Martin heeft men de Simsonbay-ers, maar dat is een verpierd en achteruitgegaan ras. Doch op Saba zijn het, hoewel hun verblijf van geslacht op geslacht in de tropen zich op hun wezen heeft afgeteekend, krachtige en taaie menschen. Misschien komt dat door hun bedrijf van zeevaarder, misschien ook door de vrij groote hoogte, waarop zij wonen.

De blanke bewoners van Saba heetten bijna allen Simmonds, Hassell of van der Pool. Men kon het op Saba treffen, dat men bijna geen man tegenkwam, want alle mannen voeren op zee. Tot Amerika in den oorlog ging, voeren zij op schoeners in de Caraïbische wateren, meestal onder Nederlandsche vlag. De Vereenigde Staten hadden echter een zeer onvoldoend aantal zeevaarders en omstreeks 1916 ontstond er groote behoefte aan scheepsruimte en ook aan de kapiteins en stuurlieden om die schepen te bedienen. Verscheidene Sabanen zijn toen naar de stoomvaart, onder Ame- 
rikaansche vlag, overgegaan en ze hebben zich, hoewel onvoldoende theoretisch opgeleid, als bekwame zeevaarders door die taak heengeslagen. Doch velen ook bleven nog op schoeners met twee, drie of vijf masten varen. En ze voelden zich daar beter op thuis. Men moet zulk een groote schoener onder volle zeilen op de zee hebben zien varen om zich de groote schoonheid daarvan bewust te worden. Maar het zeemansleven op die schoeners was een hard leven, en oud werden de Sabanen als regel niet, ook al verging hun schoener niet. Want blanken wonen nu eenmaal niet ongestraft van geslacht op geslacht in de tropen.

De Sabanen waren een merkwaardig volk, een volk om eerbied voor te hebben, voor de mannen om hun taaie durf, en voor de vrouwen om de vele opofferingen van hun eenvoudig en zuiver leven.

De kapitein van onze schoener „Estelle” was Sabaan. Hij heette Tommy van der Pool, en de „mate” heette Hassell. En al bood de „Estelle" dan niet het comfort, waaraan men in Europa was gewend geraakt, waarmede men verwend was, het was een sierlijk schip. En als „captain Tommy” bij het roer stond en commandeerde „hoist her main sail" en de matrozen dan weerom dreunden "hoist her main sail, he says", terwijl zij het zware groot-zeil met man en macht aan den mast heschen, dan bruischte het van echt leven. Of als het, met veel slagzij, onder volle zeilen lag en krakend en stampend tegen het spattende water vocht, dan vergat men Europa en comfort.

Ook op Saba werd dus de wereldoorlog beleefd, en zij bracht daar werk aan de eilandbewoners en gevaar. Anders was het op St. Eustatius, waar het tropische ,laisser aller" het van de inheemsch blanken had gewonnen. Hier geen werkzame, er op uit trekkende mannen en heldere, beschaafde vrouwen in nette huisjes. Doch hier alles slordig en verwaarloosd. Getuigen van vergane grootheid. En daartusschen de Hollandsche gezaghebber Van Grol, die, na ruim 17 jaren dienst op het primitieve eiland, nog al zijn energie en levenslust be.'aard had. Wat zeker niet het minst de verdienste was van Meviouw Van Grol, die haar Hollandsch enthousiasme had meegebracht en niet had verloren. Hun dochtertje bracht aan het gezin jeugd en vroolijkheid.

Verder was een groot voorrecht voor Statia de sisal-plantage, geleid door den Engelschman Wilde met zijn helper de heer G. baron d'Aumale van Hardenbroek, die later leider van de sisalplantage Mount-Pleasant op Curaçao is geworden. Mevrouw Wilde had aan haar huis het cachet van een Engelsch landhuis gegeven. 
Een groot deel van de gekleurde bevolking van St. Eustatius werkte op de sisal-plantage, die tegen de hellingen van den gedoofden vulkaan was gelegen. En verder was er nog wat aanplant van ,sea-island-cotton", voor welks machinale zuivering door den heer Van Grol werd gezorgd. Dat alles maakte, dat er nog eenig geld onder de menschen in omloop bleef, en voorkwam, dat het eiland geheel ten onder ging.

Ik wil St. Eustatius niet verlaten, zonder een gedachte gewijd te hebben aan de „Quill”, het inwendige van de gedoofde krater, dat wonder van wilde en weelderige, tropische plantengroei. Misschien komt het, omdat de Quill het eerste van dien aard was, dat ik ooit zag, misschien omdat de herinnering alles vermooit, maar ik ben later nooit meer zoo sterk onder den indruk van een exotisch schouwspel geweest.

In den avond van den tweeden dag na onze aankomst op St. Eustatius gingen wij weer aan boord, en in den vroegen ochtend van 30 Mei 1918 liet de „Estelle” het anker vallen in de Groote Baai van St. Martin. Wij waren aangekomen op de plaats van onze bestemming, waar wij dachten een maand of acht werk te zullen hebben, maar waar wij twee jaren hebben gewoond.

Van uit de baai gezien, is Philipsburg aan den voet van het heuvellandschap aardig gelegen. Men blijft een $400 \mathrm{~m}$ uit den wal en op dien afstand krijgt men een zeer goede algemeene indruk. De rij hooge palmen aan het Westelijk einde van het stadje - we leerden later dat het daar „down-town" heette - drukte daarop een tropisch stempel. En in het groen van de heuvelhelling in het Oosten blonk een kleine witte topgevel met een gele ster versierd. Om haar op te wekken, wees ik mijne vrouw lachend op het aardige geveltje: „Als dat ons huis eens kon zijn”. Toevallig hebben we het kunnen krijgen, we hebben er twee jaren gewoond en ons dochtertje is daar geboren.

Doch dat is een ander verhaal.

Zwolle, 20 April 1937. 